\title{
Determination of the architecture of ionotropic receptors using AFM imaging
}

\author{
Nelson P. Barrera • Robert M. Henderson • \\ J. Michael Edwardson
}

Received: 24 September 2007 / Accepted: 26 October 2007 / Published online: 17 November 2007

(C) Springer-Verlag 2007

\begin{abstract}
Fast neurotransmission in the nervous system is mediated by ionotropic receptors, all of which contain several subunits surrounding an integral ion channel. There are three major families of ionotropic receptors: the 'Cysloop' receptors (including the nicotinic receptor for acetylcholine, the $5-\mathrm{HT}_{3}$ receptor, the $\mathrm{GABA}_{\mathrm{A}}$ receptor and the glycine receptor), the glutamate receptors (including the $\alpha$-amino-3-hydroxy-5-methylisoxazole-4-propionic acid, kainate and $N$-methyl-D-aspartic acid receptors) and the $\mathrm{P} 2 \mathrm{X}$ receptors for adenosine triphosphate. These receptors are often built from multiple types of subunit, raising the question of the stoichiometry and subunit arrangement within the receptors. This question is of therapeutic significance because in some cases drug-binding sites are located at subunit-subunit interfaces. In this paper, we describe a general method, based on atomic force microscopy imaging, to solve the architecture of multi-subunit proteins, such as the ionotropic receptors. Specific epitope tags are engineered onto each receptor subunit. The subunits are then expressed exogenously in cultured cells, and the receptors are isolated from detergent extracts of membrane fractions by affinity chromatography. The receptors are imaged both alone and in complex with anti-epitope antibodies. The size of the imaged particles provides an estimate of the subunit stoichiometry, whereas the geometry of the receptor-antibody complexes produces more detailed information about the receptor architecture. We use an automated, unbiased system to identify receptors and receptor-antibody complexes and to determine the geom-
\end{abstract}

N. P. Barrera · R. M. Henderson · J. M. Edwardson $(\square)$ Department of Pharmacology, University of Cambridge,

Tennis Court Road,

Cambridge CB2 1PD, UK

e-mail: jme1000@cam.ac.uk etry of the complexes. We are also able to determine the orientation of the receptors on the mica substrate, which will allow us to solve the subunit arrangement within receptors, such as the $\mathrm{GABA}_{\mathrm{A}}$ receptor, which contain three types of subunits.

Keywords Atomic force microscopy Ionotropic receptor Subunit stoichiometry $\cdot$ Subunit arrangement

\section{Introduction}

Fast neurotransmission is mediated by ionotropic receptors, which contain several subunits arranged pseudo-symmetrically around a central ion pore [17, 30, 36, 39, 44, 47, 55, 59, 65]. Neurotransmitter binding to the receptor causes a conformational change in the receptor, which leads to the opening of the pore and a subsequent change in the firing rate of the target neuron. There are three major families of ionotropic receptors: the 'Cys-loop' receptor family, which includes the nicotinic receptor for acetylcholine, the $5-\mathrm{HT}_{3}$ receptor, the $\mathrm{GABA}_{\mathrm{A}}$ receptor and the glycine receptor $[17,36,44,59$, 65], the glutamate receptor family, comprising the $\alpha$-amino3-hydroxy-5-methylisoxazole-4-propionic acid, kainate and $N$-methyl-D-aspartic acid receptors [30, 47], and the P2X receptor family $[39,55]$. Receptors from all three families are often constructed from multiple types of subunits, raising the question of the subunit stoichiometry and arrangement within the receptor.

By far the best characterised of the Cys-loop receptors is the nicotinic acetylcholine receptor, largely thanks to the extensive electron microscopy (EM) studies of the Torpedo electroplaque form of the receptor by Unwin et al. [49, 70] and also the recent discovery of the acetylcholine binding protein in the snail $[13,18]$. This latter protein is 
homologous to the extracellular domain of the nicotinic receptor and, unlike the intact receptor, is amenable to study by X-ray crystallography. The nicotinic receptor assembles as a pentamer, composed of four types of subunits, $\alpha, \beta, \gamma$ and $\delta$, in the order $\alpha, \gamma, \alpha, \delta, \beta$, anticlockwise around the pore, when viewed from the synaptic cleft [37]. The other members of the Cys-loop family are much less well characterised. Isolated $\mathrm{GABA}_{\mathrm{A}}$ and $5-\mathrm{HT}_{3}$ receptors have been imaged by EM and appear as cylinders of length $11 \mathrm{~nm}$ and diameter 7-8 nm, with a vestibule of diameter 2-3 nm $[11,12,52]$. The pentameric structure of the channels is clearly visible in the EM images. By analogy, the glycine receptor is also assumed to be pentameric [17]. The glutamate receptors are all tetramers $[30,47]$. Fortuitously, they have a large extracellular domain and a modular structure, which has permitted the application of both X-ray crystallography and homology modelling, resulting in the production of extensive structural information [30, 47]. The P2X receptors are relatively poorly characterised. Cross-linking studies have indicated that they are trimeric $[2,54]$, although there have also been suggestions that they are tetramers [40], hexamers or even nonamers [2, 54]. Isolated receptors have been imaged both by EM [48] and by atomic force microscopy (AFM) under fluid [50]. Their large extracellular domains appear to be arranged in the form of crown-shaped structures, perhaps containing an inner vestibule.

Despite the availability of quite detailed structural information, the arrangement of subunits within the ionotropic receptors is often unclear. Even in the case of the nicotinic acetylcholine receptor, agreement about the subunit arrangement was not reached until fairly recently $[37,49,70]$, and the composition of the other members of the Cys-loop family is still largely unclear. In the case of the $\mathrm{GABA}_{\mathrm{A}}$ receptors in particular, the subunit arrangement is of therapeutic significance, as drugs such as the benzodiazepines are known to bind at subunit-subunit interfaces [65]. The glutamate receptors are often heteromeric, although the subunit arrangements are again unknown $[30,47]$. P2X receptors are known to exist as both homomers and heteromers [2, 27, 34, 41, 54, 55], and the heteromers have different characteristics from the parent homomers [27, 34, 41], indicating that the properties of endogenous receptors may vary in subtle ways depending on the subunit composition.

One method to determine the arrangement of subunits within ionotropic receptors involves generating constructs in which the subunits are joined together by linker sequences, to form concatemers. This procedure forces the subunits into predetermined arrangements. The functionality of various arrangements can then be tested in heterologous expression systems such as Xenopus oocytes or transfected mammalian cells. This method has been successfully applied to the $\alpha_{1} \beta_{2} \gamma_{2}$ form of the GABA receptor. Different combinations of subunits were concatenated as trimers and dimers, and various trimer/dimer pairs were expressed in Xenopus oocytes [8]. Many combinations did not give functional receptors. From the minority of combinations that did lead to functional expression, it was possible to deduce that the likely subunit arrangement was $\alpha \beta \alpha \gamma \beta$, anti-clockwise when viewed from the outside the cell. This arrangement was later confirmed by the concatenation of all five subunits in this order [9]. A similar result has recently been reported for the neuronal nicotinic acetylcholine receptor containing $\alpha_{3}$ and $\beta_{4}$ subunits. It was shown that a $\beta \beta \alpha \beta \alpha$ concatemer had characteristics very similar to those of receptors built from monomeric $\alpha$ and $\beta$-subunits [31].

Subunit concatenation undoubtedly provides valuable information about the assembly of ionotropic receptors. However, the construction of the concatemers is rather laborious, and progress using it has been slow. In addition, there is concern that receptors might be forcibly produced that do not exist in vivo. We have sought an alternative method that more directly examines the architecture of receptors constructed form individual subunits. The AFMbased method described here is rapid, robust and generally applicable to a wide variety of multi-subunit proteins.

\section{General features of the AFM-based method}

In our method, epitope tags (one of which must be $\mathrm{His}_{6}$ ) are engineered onto individual receptor subunits, and the receptors are expressed exogenously by transfection of a suitable cell line (tsA 201). The cells are lysed, and a membrane fraction is prepared. The membrane fraction is solubilised in detergent, and the receptors are isolated from the detergent extract through the binding of the $\mathrm{His}_{6}$ tag to $\mathrm{Ni}^{2+}$-agarose beads. The receptors are eluted from the beads by incubation with imidazole. The receptors are then bound to a mica substrate and imaged by AFM. The molecular dimensions of a large number of the bound receptor particles are measured and used to calculate particle molecular volumes. A frequency distribution of molecular volumes is produced, and the peak volumes are then compared with the volume expected for an individual subunit, calculated on the basis of its molecular mass. This process produces an estimate of the likely subunit stoichiometry of the receptor. The receptors are then incubated with antibodies against the epitope tags on the subunits. The receptor-antibody complexes are bound to mica and again imaged by AFM. Receptors decorated by two antibodies are identified in the AFM images, and the angles between the bound antibodies are measured. A frequency distribution of angles is produced. The peak angles define 
the geometry of the receptor, which in turn reveals its subunit stoichiometry. When the receptor contains more than one type of subunit, the antibody tagging is repeated for each subunit. In this way, the subunit arrangement within the receptor can be determined.

\section{Receptor isolation}

In a typical experiment, we transfect tsA 201 cells growing on five $162-\mathrm{cm}^{2}$ culture flasks with the appropriate complementary deoxyribonucleic acid(s) (cDNA). We then wait for $48 \mathrm{~h}$ to allow receptor expression. Cells are lysed, and nuclei and cell debris are pelleted by low-speed centrifugation $(700 \times g$ for $5 \mathrm{~min}$ in a cooled Eppendorf bench centrifuge). The supernatant from this step is spun at $21,000 \times g$ for $15 \mathrm{~min}$ in the same centrifuge. The pellet from this spin is dissolved in a detergent solution (usually $1 \%$ CHAPS) by incubation at $4^{\circ} \mathrm{C}$ for $1 \mathrm{~h}$ on a rotating wheel. Unsolubilised material is precipitated by centrifugation at $100,000 \times g$ for $1 \mathrm{~h}$, and the supernatant is then incubated with pre-washed $\mathrm{Ni}^{2+}$-agarose beads at $4{ }^{\circ} \mathrm{C}$ for $30 \mathrm{~min}$. The beads are washed three times in buffer, and the bound receptor is eluted with two $500-\mu 1$ batches of $200 \mathrm{mM}$ imidazole followed by one $500-\mu \mathrm{l}$ batch of $400 \mathrm{mM}$ imidazole. The receptor is usually found mainly in the second 200-mM imidazole batch.

We find that CHAPS efficiently solubilises the receptors that we have studied. However, there is no particular reason why this detergent should be used. Our advice would be to optimise the procedure by trialling a number of detergents, checking for yield and stability of the oligomeric receptor during isolation. The protein yields in our receptor preparations are low. We typically concentrate a fraction of the eluted receptor, using centrifugation in Centricon ${ }^{\mathrm{TM}}$ columns, and then run immunoblots of the concentrated material to check for the presence of the receptor subunits. It is also possible to use silver-stained gels to check for the purity of the sample. An alternative method for checking purity is to run a batch of non-transfected cells in parallel with the receptor isolation and to compare the AFM images of samples obtained from transfected and non-transfected cells. In our experience, the images given by samples from non-transfected cells are usually almost featureless, in contrast to the receptor isolates, which appear as spreads of protein particles (Fig. 1).

\section{Receptor imaging}

Isolated proteins are diluted to a final concentration of about $40 \mathrm{pM}$, and a $45-\mu 1$ solution of the protein is added to a poly-L-lysine-coated 1-cm mica disc attached to a steel puck. The proteins are allowed to adsorb to the mica for $10 \mathrm{~min}$. The surface of the mica is then washed with Milli$Q$ water and dried under nitrogen. Imaging is performed with a Multimode atomic force microscope (Digital Instruments). Samples are imaged in air, using the tapping mode. The silicon cantilevers used have a drive frequency $\sim 300 \mathrm{kHz}$ and a specified spring constant of $40 \mathrm{~N} / \mathrm{m}$ (Mikromasch). The applied imaging force is kept as low as possible (target amplitude $\sim 1.6-1.8 \mathrm{~V}$ and amplitude setpoint $\sim 1.3-1.5 \mathrm{~V})$.

The molecular volumes of the protein particles are determined from particle dimensions based on AFM images. After adsorption of the receptors onto the mica support, the particles adopt the shape of a spherical cap. The heights and half-height radii are measured, and the molecular volume is calculated using the following equation:

$V_{\mathrm{m}}=(\pi h / 6)\left(3 r^{2}+h^{2}\right)$

where $h$ is the particle height and $r$ is the radius [62].

Molecular volume based on molecular mass can be calculated using the equation

$V_{\mathrm{c}}=\left(M_{0} / N_{0}\right)\left(V_{1}+d V_{2}\right)$

where $M_{0}$ is the molecular mass, $N_{0}$ is Avogadro's number, $V_{1}$ and $V_{2}$ are the partial specific volumes of particle and
Fig. 1 Typical AFM images of samples prepared from nontransfected (a) and transfected (b) tsA 201 cells. The image in b, adapted from Barrera et al. [6], shows a homogenous spread of particles in a sample isolated from cells transfected with cDNA for the $\mathrm{P} 2 \mathrm{X}_{2}$ receptor subunit. The mean molecular volume of these particles is $409 \mathrm{~nm}^{3}$, close to the volume expected for a homotrimer $\left(390 \mathrm{~nm}^{3}\right)$
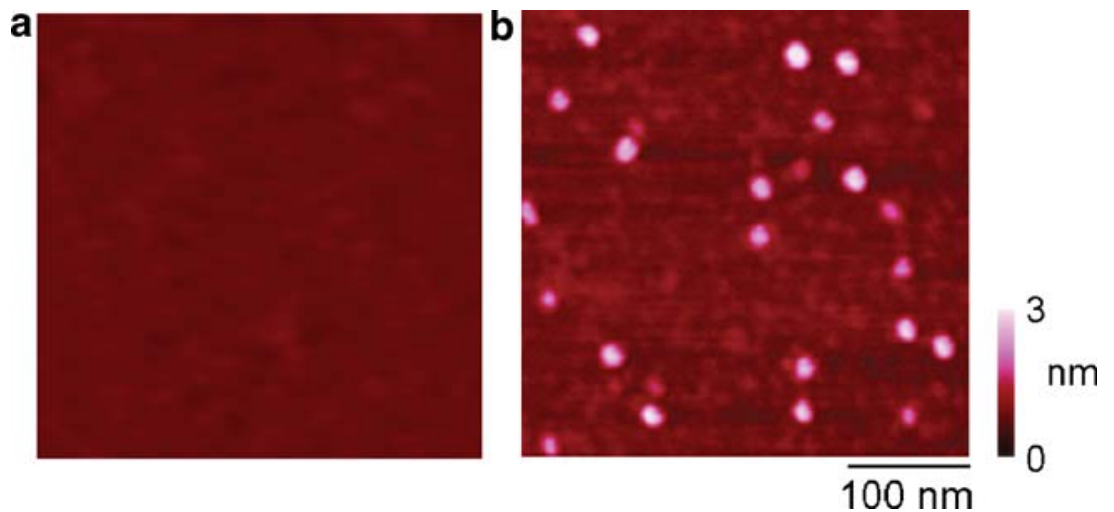
water, respectively, and $d$ is the extent of protein hydration [62]. Because ionotropic receptors are glycoproteins, the volume contributions of core protein and attached oligosaccharides should ideally be calculated separately. Partial specific volumes for protein $\left(0.74 \mathrm{~cm}^{3} / \mathrm{g}\right)$ and carbohydrate $\left(0.61 \mathrm{~cm}^{3} / \mathrm{g}\right)$ have been reported previously [26]. The extent of glycosylation of a receptor subunit can be determined by comparing the mobilities on gels of fully glycosylated protein and protein that has been deglycosylated with $N$ glycanase F (e.g. [6]).

When the receptors are dried down, they flatten extensively on the mica substrate, likely because of electrostatic attractions between the protein and the polyL-lysine used to coat the mica. Consequently, the shape of the protein will become distorted into the spherical cap normally observed. It has been shown previously, however, that there are no significant differences in molecular volumes determined under fluid and in air [62]. Thus, for the extent of protein hydration, we routinely use the value of $0.4 \mathrm{~g}$ of water per gram of protein reported for a typical globular protein (human serum albumin) in solution [29]. Particle radii are measured at half the maximal height of the particle in an attempt to compensate for the tendency of AFM to overestimate this parameter when the radii of both particle and tip are similar (i.e. in the nanometre range). By using this method, a very good correlation has been obtained between predicted and calculated molecular volumes for proteins of widely varying molecular masses [62]. Nevertheless, given all the caveats associated with this procedure (i.e., distortion of the protein during attachment, the likely presence of detergent, convolution of the image because of the geometry of the scanning tip), we feel that it is unsatisfactory to rely on volume measurements alone to determine the stoichiometry of the receptor. In this respect, antibody tagging is a powerful corroborative technique.

\section{Imaging of receptor-antibody complexes}

We have imaged receptors containing a number of different epitope tags- $-\mathrm{His}_{6}$, haemagglutinin (HA), V5, Myc and FLAG. Suitable monoclonal antibodies for receptor decoration are commercially available for all of these tags. Tags can be attached either to the $\mathrm{N}$ terminus or the $\mathrm{C}$ terminus of the receptor subunit, and the choice of location will depend on where a tag can be added without affecting the assembly of the receptor. Whether or not the tag has any effect on the properties of the receptor should ideally be tested functionally. To some extent, the incubation conditions between receptor and antibody need to be determined by trial and error. The ideal concentrations of receptor and antibody will depend on the yield of receptor from the isolation procedure, which can vary. Typically, we incubate the receptor at a concentration of around $0.2 \mathrm{nM}$ with antibody at around $0.4 \mathrm{nM}$. The incubation is overnight (about $14 \mathrm{~h}$ ) at $4{ }^{\circ} \mathrm{C}$. After the incubation, the proteins are diluted to a final concentration of about $40 \mathrm{pM}$, before addition of a $45-\mu l$ aliquot to the mica. This procedure will give a spread of receptors decorated with antibodies. Typically, around $20-25 \%$ of the receptors have one bound antibody, and about $7-10 \%$ of them have two bound antibodies. Few receptors are seen with more than two antibodies bound, as expected from the binomial distribution. Of course, it is theoretically possible to increase the efficiency of decoration by using a higher concentration of antibody. However, because most receptors have more than one subunit that is recognised by the antibody, the receptors and antibodies will tend to form a network, resulting in the production of protein aggregates at higher concentrations of antibody. The method that we use results in the production of a satisfactory number of doubly decorated receptors, which is the key to the success of the method. One possible way to circumvent the problem of aggregate formation is to use Fab fragments of antibodies, which are monovalent. We have found recently that Fab fragments do bind to epitope tags on receptors. However, we have not yet explored their use in producing more efficient receptor decoration.

The concentrations of receptor and antibody detailed above result in the production of a spread of reasonably well-separated particles. The AFM images are analysed, and the numbers of receptors that are undecorated or decorated by either one or two antibodies are counted. Of course, it is necessary to be sure that an antibody is really bound to a receptor and has not simply attached next to it on the mica. To check this, we run two control experiments-imaging receptors alone and after incubation with a control antibody against an epitope tag not present on the receptor. We then compare the tagging profiles for the various conditions and confirm that the positive conditions give a significantly greater number of antibody-tagging events. We also measure the height of the 'saddle' between the receptor and the antibody and consider only those events where the saddle is at least $0.2 \mathrm{~nm}$ high to be genuine tagging events.

Once a reasonable number (i.e. at least 40 ) of receptors doubly decorated by antibodies have been identified, we then measure the angles between the two bound antibodies by joining the height peaks of the antibody to the height peak of the receptor. We then produce a frequency distribution of the angles and determine where the peaks of the distribution lie. The angle peaks provide the key information about the subunit stoichiometry and arrangement within the receptor. The angle peaks are typically broad, likely reflecting both flexibility in the attachment of the antibody to the receptor and the fact that the receptors 
attach to the mica in a variety of orientations. This latter complication is discussed further below.

\section{Automated recognition of receptors and receptor-antibody complexes}

Our AFM analysis involves the measurement of the dimensions of receptor particles using the AFM software. In addition, we measure the angles between antibodies attached to the receptor subunits, performing a geometric analysis of complexes. Initially, we carried out this analysis manually, which is an extremely laborious process. For a large data set, an operator will have to interpret several hundred images, while a typical image may contain more than a hundred receptors and/or receptorantibody complexes.

We have now developed a framework for the automation of our AFM analysis [3] and validated it on $\mathrm{P}_{2} \mathrm{X}_{6}$ receptors, which we had already characterised extensively. The receptors were isolated and subjected to AFM analysis. We compared the results obtained by the conventional manual analysis with those given by the automated scheme. We found that the two methods generated very similar results, suggesting that this automated method can be used for determining the architecture of other multi-subunit protein complexes. We now apply the method routinely in our analyses.

\section{Homo-oligomeric receptors}

We first applied our method to a relatively simple ionotropic receptor system- $\mathrm{P} 2 \mathrm{X}$ receptor homomers [6]. We began by addressing the stoichiometry of the $\mathrm{P} 2 \mathrm{X}_{2}$ receptor homomer. $\mathrm{A} \mathrm{His}_{6}$ tag was engineered onto the $\mathrm{N}$ terminus of the $\mathrm{P} 2 \mathrm{X}_{2}$ receptor subunit, and the receptors were expressed in tsA 201 cells and isolated as described above (Fig. 1). When the receptors were imaged, the molecular volume distribution had a single peak at $409 \mathrm{~nm}^{3}$. The predicted size of a single $\mathrm{P} 2 \mathrm{X}_{2}$ receptor subunit is $130 \mathrm{~nm}^{3}$. Hence, the measured size was close to the value expected for a trimer $\left(390 \mathrm{~nm}^{3}\right)$. The small discrepancy between measured and expected values is likely a consequence of the presence of detergent attached to the isolated receptors. To confirm the trimeric arrangement of subunits, we incubated the receptor with an antibody against its epitope tag and imaged the receptorantibody complexes. We found that the frequency distribution for angles between pairs of antibodies bound to the receptor had a single peak at $123^{\circ}$ (Fig. 2). This result (close to $120^{\circ}$ ) again pointed to a trimeric structure for the $\mathrm{P} 2 \mathrm{X}_{2}$ receptor.

Unlike the $\mathrm{P} 2 \mathrm{X}_{2}$ receptor, the $\mathrm{P} 2 \mathrm{X}_{6}$ receptor, when expressed exogenously in cells such as Xenopus oocytes or cultured olfactory bulb neurons, is not efficiently delivered to the plasma membrane $[2,10]$. Instead, transport of the receptor is arrested in the endoplasmic reticulum, suggesting that it might be retained by the 'quality control' machinery of the cell. A possible reason for this retention is that it is not being correctly assembled, perhaps because the $\mathrm{P} 2 \mathrm{X}_{6}$ receptor subunits are unable to oligomerise. To test this idea, we produced $\mathrm{P}_{2} \mathrm{X}_{6}$ subunits tagged at their $\mathrm{C}$ termini with a $\mathrm{His}_{6}$ epitope tag. When we imaged the receptor by AFM, the receptor particles were clearly smaller than those seen with $\mathrm{P} 2 \mathrm{X}_{2}$, and the molecular volume frequency distribution had a single peak at $145 \mathrm{~nm}^{3}$, close to the predicted value of $97 \mathrm{~nm}^{3}$ for a single $\mathrm{P}_{2} \mathrm{X}_{6}$ receptor subunit. This AFM analysis, therefore, confirmed that the $\mathrm{P}_{2} \mathrm{X}_{6}$ receptor is unable to oligomerise [6].

To account for the failure of the $\mathrm{P} 2 \mathrm{X}_{6}$ receptor subunit to oligomerise, we looked for anomalous features in the $\mathrm{P}_{2} \mathrm{X}_{6}$ receptor sequence. Of the seven $\mathrm{P} 2 \mathrm{X}$ receptor isoforms, the $\mathrm{P} 2 \mathrm{X}_{6}$ subunit has a particularly hydrophobic $\mathrm{N}$ terminus. We speculated that this region might interact with an (unknown) ER chaperone protein in such a way as to prevent its assembly into receptor oligomers. Assuming that this interaction was likely to be hydrophobic, we added positive charge to this $\mathrm{N}$-terminal region by mutating two serine residues (residues 3 and 11) to lysines. We found that the introduction of these mutations caused a fourfold
Fig. 2 Analysis of complexes between $\mathrm{P} 2 \mathrm{X}_{2}$ receptors and antibodies against an $\mathrm{N}$-terminal $\mathrm{His}_{6}$ tag. a Representative AFM image of a receptor liganded by two antibodies. b Distribution of angles between pairs of bound antibodies. The mean angle is $123^{\circ}$, close to the value expected for a homotrimer $\left(120^{\circ}\right)$. The figure is adapted from Barrera et al. [6]
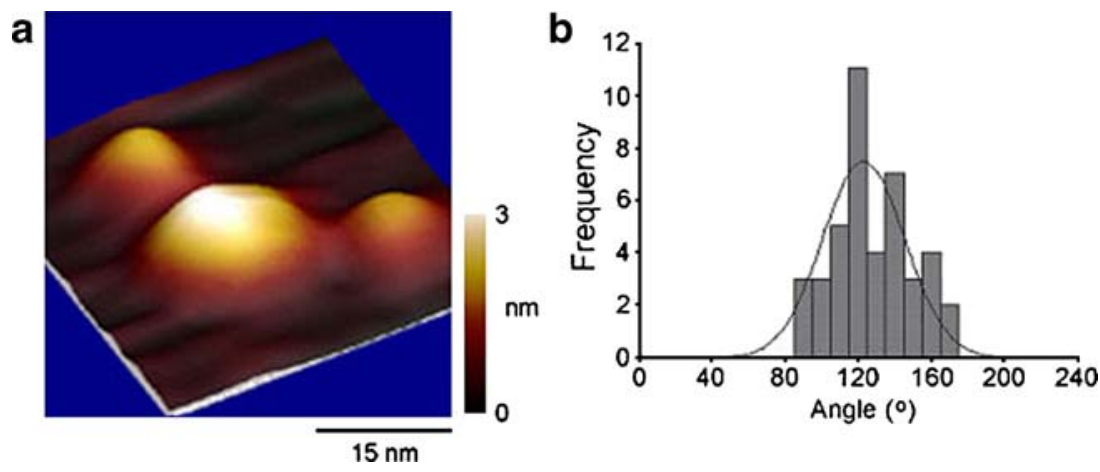
increase in cell surface expression of the receptor. When we expressed the mutated sequence in tsA 201 cells, isolated the receptors and imaged them by AFM, we found two types of particles-large and small [57]. The frequency distribution of molecular volumes now had two peaks, at 120 and $340 \mathrm{~nm}^{3}$, consistent with the presence of both monomers and trimers. Analysis of the numbers of particles within the two peaks indicated that $42 \%$ of the particles were receptor trimers. We also imaged the isolated mutant $\mathrm{P}_{2} \mathrm{X}_{6}$ receptors after incubation with an anti-His ${ }_{6}$ antibody that recognises the $\mathrm{C}$-terminal $\mathrm{His}_{6}$ tag. We found that some of the larger particles were decorated with one, two or occasionally three antibodies. The angles between pairs of bound antibodies were measured, and a frequency distribution of angles was constructed. The distribution had a single peak at $124^{\circ}$, confirming that the mutant receptor was able to form homotrimers.

Our results suggest that the $\mathrm{N}$ terminus of the $\mathrm{P} 2 \mathrm{X}_{6}$ receptor is normally preventing its assembly into trimers. It is known that the $\mathrm{P} 2 \mathrm{X}_{6}$ subunit can associate with both $\mathrm{P} 2 \mathrm{X}_{2}$ and $\mathrm{P} 2 \mathrm{X}_{4}$ to form heteromeric receptors, which have properties distinct from the corresponding homomers [27, 41]. Furthermore, $P 2 X_{6}$ is co-localized with both $P 2 X_{2}$ and $\mathrm{P} 2 \mathrm{X}_{4}$ in many parts of the central and peripheral nervous systems $[22,42,43,61,64,66,69,72]$. It is possible, therefore, that the $\mathrm{P} 2 \mathrm{X}_{6}$ subunit operates as a modulatory subunit rather than a receptor in its own right. The retention of $\mathrm{P} 2 \mathrm{X}_{6}$ in the endoplasmic reticulum would then prevent non-functional subunits from reaching the cell surface and provide an intracellular pool of subunits ready to be incorporated into heteromeric receptors. Furthermore, the role of $\mathrm{P}_{2} \mathrm{X}_{6}$ as a modulatory subunit might be regulated in response to changes in circumstances. For example, expression of $\mathrm{P} 2 \mathrm{X}_{6}$ is known to change under pathological conditions such as cancer and zinc deficiency [20, 51, 58, 71]. We have begun to examine the control of P2X heteromer assembly, and these results are discussed below.

Another receptor homomer that we have studied is the 5- $\mathrm{HT}_{3 \mathrm{~A}}$ receptor. This receptor belongs to the Cys-loop superfamily, and EM imaging of isolated native $5-\mathrm{HT}_{3}$ receptors has revealed the pentameric structure characteristic of this receptor superfamily $[11,12]$. Two $5-\mathrm{HT}_{3}$ receptor subunits have been identified-A [46] and B [23, 25]. The A-subunit forms functional receptor homomers, whereas the B-subunit forms $5-\mathrm{HT}_{3 \mathrm{~A} / \mathrm{B}}$ receptor heteromers but not homomers. We expressed $5-\mathrm{HT}_{3 \mathrm{~A}}$ subunits bearing a Myc-His ${ }_{6}$ tag at its $\mathrm{C}$ terminus in tsA 201 cells [5]. When the isolated receptor was imaged, the frequency distribution of molecular volumes was broad, with a peak at $757 \mathrm{~nm}^{3}$. The value predicted on the basis of the molecular mass of a $5-\mathrm{HT}_{3 \mathrm{~A}}$ receptor pentamer was $511 \mathrm{~nm}^{3}$. Hence, the discrepancy between observed and predicted molecular volumes was much greater that was seen for the $\mathrm{P} 2 \mathrm{X}_{2}$ receptor (above). One likely reason for this is the presence of twenty transmembrane domains in a $5-\mathrm{HT}_{3}$ receptor pentamer (compared with only six in a $\mathrm{P} 2 \mathrm{X}_{2}$ receptor trimer), which would attract a greater amount of bound detergent. Incidentally, this result does emphasize the difficulty in trying to estimate the subunit stoichiometry of a transmembrane receptor on the basis of molecular volume calculation alone. We next imaged the receptor in complex with either anti-Myc or anti-His ${ }_{6}$ antibodies. In both cases, singly and doubly tagged receptors were seen, and the occurrence of these complexes was far more common than was seen when a control antibody (antiV5), or no antibody was used, indicating that both anti-Myc and anti-His ${ }_{6}$ antibodies specifically decorate the receptor. For both antibodies, the frequency distribution for angles between pairs of bound antibodies had two peaks, one at around $72^{\circ}$ and one at around $144^{\circ}$, consistent with the decoration of either adjacent or non-adjacent subunits in a receptor pentamer. The areas under the two angle peaks were approximately equal, indicating that there was no preference for the binding of the pairs of antibodies at either an acute or an obtuse angle. Hence, there was no evidence for steric hindrance in the binding of the antibodies to the receptor.

Our results for homomeric receptors indicate that our method gives accurate information about subunit stoichiometry. We now go on to consider the application of this technology to more interesting examples where the receptor contains two or more different subunits.

\section{Receptors containing two types of subunit}

We alluded above to the fact that $\mathrm{P} 2 \mathrm{X}_{6}$ subunits are able to form hetero-oligomers with both $\mathrm{P} 2 \mathrm{X}_{2}$ and $\mathrm{P} 2 \mathrm{X}_{4}$. We decided to examine the stoichiometry of $\mathrm{P} 2 \mathrm{X}_{2 / 6}$ heteromers and specifically to test the idea that the stoichiometry of a P2X heteromer might be plastic and dependent on relative levels of subunit expression. To do this, we engineered different tags on the two subunits-initially $\mathrm{His}_{6}$ on $\mathrm{P} 2 \mathrm{X}_{2}$ and $\mathrm{HA}$ on $\mathrm{P}_{2} \mathrm{X}_{6}$. When we compared the expression of the two subunits in cells that had been transfected with a mixture of equal amounts of the two cDNAs by immunoblotting, we found that the ratio of expression of the two subunits was about $4 \mathrm{P}_{2} \mathrm{X}_{2}: 1 \mathrm{P}_{2} \mathrm{X}_{6}$ [4]. When His $_{6}$ containing proteins were isolated and imaged, the frequency distribution for molecular volumes had three peaks, at 115,217 and $360 \mathrm{~nm}^{3}$. Because the predicted volumes of $\mathrm{P} 2 \mathrm{X}_{2}$ and $\mathrm{P} 2 \mathrm{X}_{6}$ subunits are around 130 and $97 \mathrm{~nm}^{3}$, respectively, the peaks likely represent receptor monomers, dimers and trimers. Each particle in the AFM images could be assigned on the basis of its size to one of these peaks. When the receptors were incubated with either anti-His ${ }_{6}$ or 
anti-HA antibodies, large particles, corresponding to receptor trimers, decorated by the antibodies could be identified. We found that there were about five times as many receptors decorated by two anti-His 6 antibodies as by two anti-HA antibodies. Hence, the numbers of receptors doubly decorated by one antibody or the other were in the approximate ratio of subunit expression. Furthermore, when the epitope tags on the subunits were switched, to produce HA-tagged $\mathrm{P} 2 \mathrm{X}_{2}$ and $\mathrm{His}_{6}$-tagged $\mathrm{P} 2 \mathrm{X}_{6}$, the antibody decoration profile was reversed. Next, we changed the ratio of cDNAs used in the transfection so that 2.5 times as many $\mathrm{P} 2 \mathrm{X}_{6}$ subunits as $\mathrm{P} 2 \mathrm{X}_{2}$ subunits were expressed. When the receptors were isolated, we found that about 2.5 times as many receptors were doubly decorated with anti-HA antibodies (against the tag on the $\mathrm{P}_{2} \mathrm{X}_{6}$ subunit) as by anti-His 6 antibodies (against the tag on the $\mathrm{P}_{2} \mathrm{X}_{2}$ subunit). Our conclusion from these results was that the subunit stoichiometry of the $\mathrm{P} 2 \mathrm{X}_{2 / 6}$ hetero-oligomer depends on the relative levels of subunit expression.

The antibody decoration profile of the $5-\mathrm{HT}_{3 \mathrm{~A}}$ receptor homomer has been described above. Although 5- $\mathrm{HT}_{3 \mathrm{~A}}$ homomers probably exist in vivo, most endogenous $5-\mathrm{HT}_{3}$ receptors have properties consistent with the presence of both A- and B-subunits [24, 32, 35, 73]. For instance, the 5$\mathrm{HT}_{3 \mathrm{~A}}$ homomer has a much lower single-channel conductance than the 5- $\mathrm{HT}_{3 \mathrm{~A} / \mathrm{B}}$ heteromer, and the Hill slope for agonist activation of the homomer is higher than that for the heteromer [23, 25, 38]. We were interested, therefore, in determining the subunit stoichiometry and arrangement of the $5-\mathrm{HT}_{3 \mathrm{~A} / \mathrm{B}}$ receptor heteromer. Because the receptor is a pentamer, the possible permutations containing two subunits are more complex than for the trimeric $\mathrm{P} 2 \mathrm{X}$ receptor. Specifically, there are six ways in which a pentamer containing A- and B-subunits can be built (Fig. 3). To solve the receptor architecture, we engineered different epitope tags on the two subunits-Myc-His ${ }_{6}$ on the Asubunit and $\mathrm{V}^{5}-\mathrm{His}_{6}$ on the B-subunit [5]. We transfected
tsA 201 cells with equal amounts of the two cDNAs, and isolated receptors from the transfected cells. After AFM imaging of the receptor alone, the frequency distribution of the molecular volumes was broad (as for the 5-HT $3 \mathrm{~A}$ receptor) and had a single peak at $704 \mathrm{~nm}^{3}$, smaller than the value for the $5-\mathrm{HT}_{3 \mathrm{~A}}$ homomer, which was expected because the B-subunit has a lower molecular mass than the A-subunit. When the receptors were incubated with either anti-His 6 , anti-Myc or anti-V5 antibodies, doubly decorated receptors were observed (Fig. 4a). The frequency distributions of angles between pairs of bound antibodies had two peaks, at about 72 and about $144^{\circ}$, for both antiHis $_{6}$ and anti-V 5 antibodies, but only one peak, at $144^{\circ}$, for the anti-Myc antibody (Fig. 4b). These results indicate that pairs of B-subunits (with the V5 tag) can either be adjacent or non-adjacent but that pairs of A-subunits (with the Myc tag) could only be non-adjacent. The only subunit stoichiometry and arrangement that is consistent with this antibody decoration profile is B-B-A-B-A (arrangement 'e' in Fig. 3).

\section{Receptors containing three types of subunit — determination of the orientation of the receptor}

Many types of $\mathrm{GABA}_{\mathrm{A}}$ receptor contain three different subunits [45]. The most common form of the receptor in the brain is the $\alpha_{1} \beta_{2} \gamma_{2}$ form [45], which has the subunit stoichiometry $2 \alpha: 2 \beta: 1 \gamma$ [28]. The subunit arrangement within the receptor has been shown by the use of subunit concatenation to be $\alpha, \beta, \alpha, \gamma, \beta$, anti-clockwise when viewed from the outside of the cell $[8,9]$. The AFM-based method described above (e.g. for the $5-\mathrm{HT}_{3 \mathrm{~A} / \mathrm{B}}$ heteromer) should be able to demonstrate that neither the two $\alpha$ subunits nor the two $\beta$-subunits are adjacent. Indeed, we showed several years ago, by placing a $\mathrm{His}_{6}$ epitope tag on the $\alpha$-subunit and imaging complexes between the isolated
Fig. 3 Six possible subunit arrangements in a $5-\mathrm{HT}_{3 \mathrm{~A} / \mathrm{B}}$ receptor heteromer
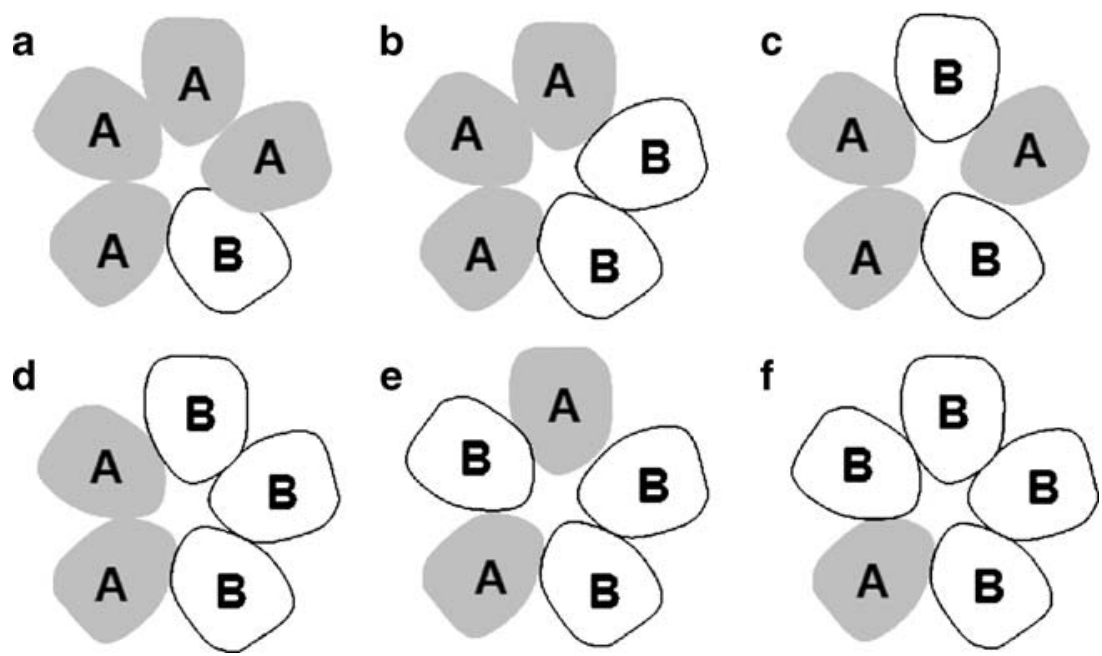
a

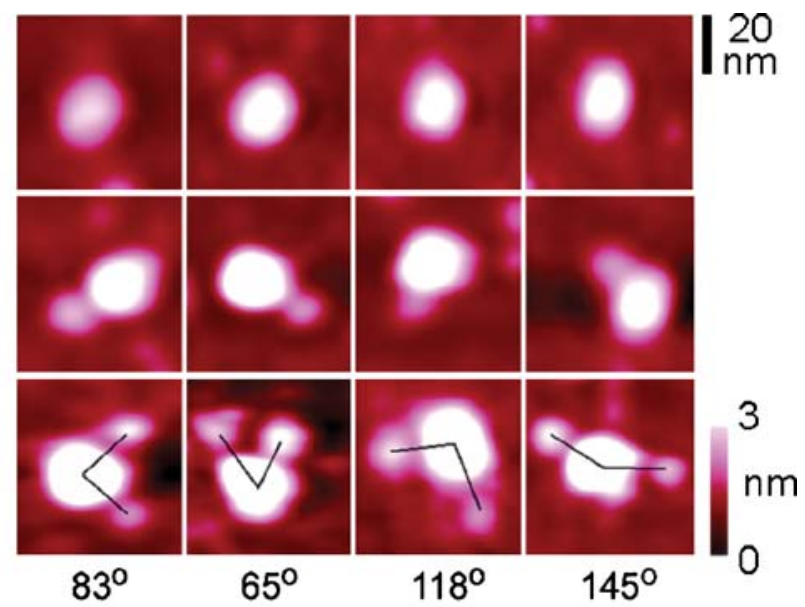

b

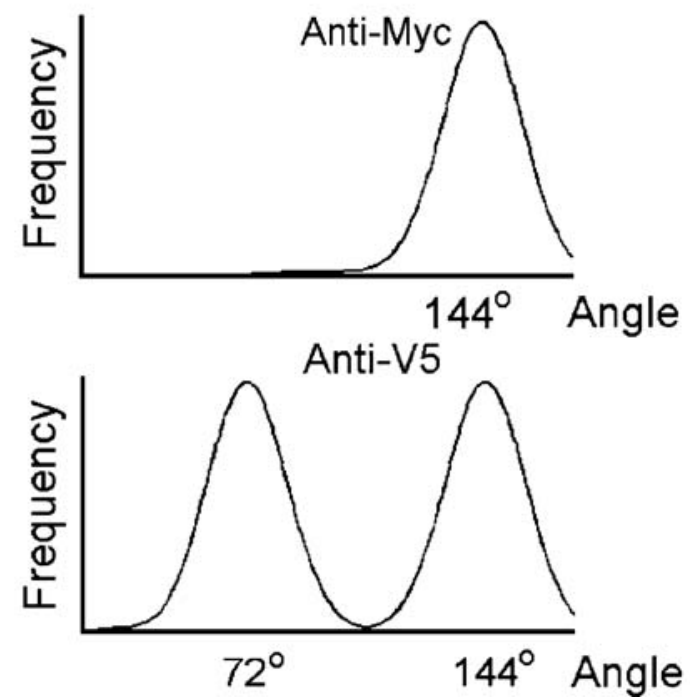

Fig. 4 Analysis of complexes between $5-\mathrm{HT}_{3 \mathrm{~A} / \mathrm{B}}$ receptors and subunit-specific antibodies. a Gallery of images, adapted from Barrera et al. [5], of receptors that are either unliganded (top row) or liganded by either one (middle row) or two anti-V5 antibodies (bottom row), directed against the B-subunit. b Schematic illustration of the distribution of angles between pairs of anti-Myc antibodies, directed against the A-subunit (top) and anti-V5 antibodies (bottom). In the study reported in Barrera et al. [5], 40 receptor-antibody complexes were analysed in each case. The angle distributions indicate that the subunit arrangement around the central ion pore is B-B-A-B-A

receptor and anti-His ${ }_{6}$ antibodies, that this receptor contains two non-adjacent $\alpha$-subunits [53]. However, determination of the absolute subunit arrangement by AFM analysis requires finding the position of the $\gamma$-subunit (for example) in relation to the $\alpha$ - and $\beta$-subunits, to distinguish between the arrangements $\alpha \beta \alpha \gamma \beta$ and $\alpha \beta \alpha \beta \gamma$. Two further advances are needed to accomplish this task: (1) decoration of the receptor simultaneously with distinguishable ligands for two types of subunit and (2) determination of the orientation of the receptor on the mica support.

We have addressed these challenges using the $\alpha_{4} \beta_{3} \delta$ form of the receptor as a model system. The $\alpha_{4} \beta_{3} \delta$ receptor, although a minor component of the total $\mathrm{GABA}_{\mathrm{A}}$ receptor population, has some interesting properties, such as an extrasynaptic location $[14,56,67]$, a high sensitivity to GABA $[1,16]$ and a slow rate of desensitization [16], factors that allow it to exert a tonic inhibition of neuronal excitability [19]. It also has a potential involvement in epilepsy $[15,21,63,68]$. Consequently, it is a promising target for the development of novel drugs.

We transfected tsA 201 cells with cDNAs for $\alpha_{4^{-}}, \beta_{3^{-}}$ and $\delta$-subunits. The $\alpha$-subunit had a FLAG-His ${ }_{6}$ epitope tag, the $\beta$-subunit had a V5-His 6 tag, and the $\delta$-subunit had

a

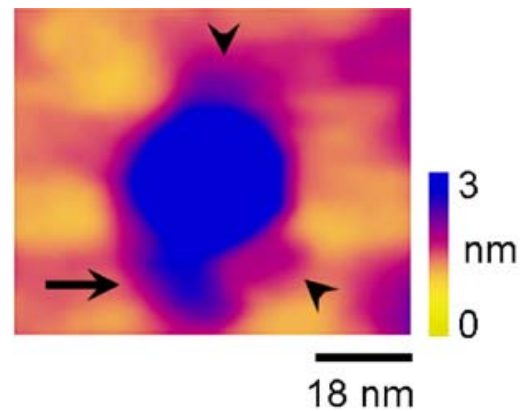

b Mainly extracellular face down

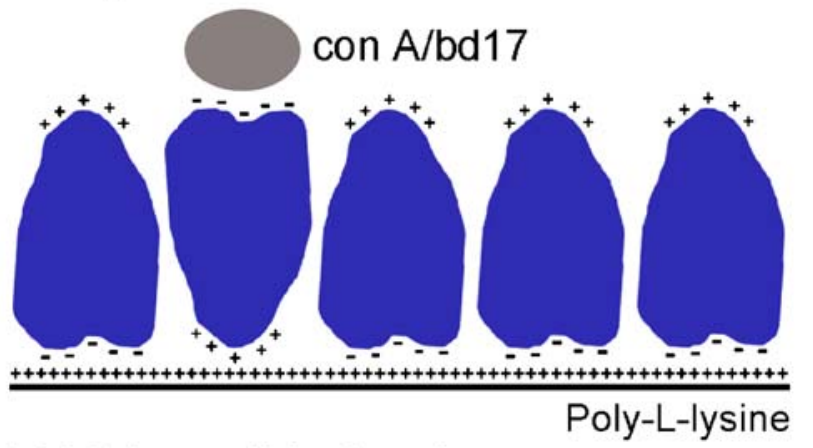

Mainly intracellular face down

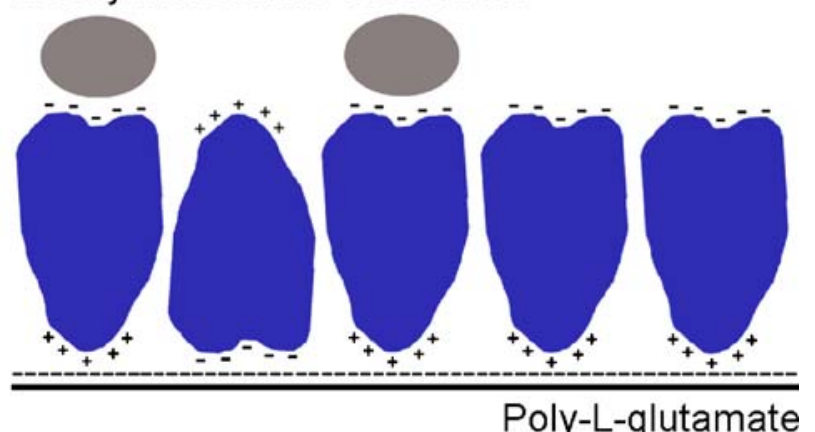

Fig. 5 AFM analysis of $\alpha_{4} \beta_{3} \delta \mathrm{GABA}_{\mathrm{A}}$ receptors. a Representative AFM image of a receptor (large central particle) liganded by one antiHA antibody, directed against the $\delta$-subunit (larger peripheral particle, arrow), and two anti-FLAG Fab fragments, directed against the two $\alpha$-subunits (smaller peripheral particles, arrowheads). b Illustration of the experiment designed to determine the orientation of the receptor on the mica support. Twice as many receptors were decorated with concanavalin A (con $A$ ) or monoclonal antibody bd17 when the receptors were bound to poly-Lglutamate than when they were bound to poly-L-lysine, indicating that the receptors normally prefer to bind extracellular face down to poly-L-lysine-coated mica 
an $\mathrm{HA}^{-\mathrm{His}_{6}}$ tag. All tags were on the $\mathrm{C}$ termini of the subunits. Receptors were isolated from the transfected cells by the usual procedure. Fab fragments of the anti-FLAG antibody were generated using papain digestion. When receptors were incubated with these Fab fragments, receptorFab complexes were produced (Barrera et al., unpublished data). A frequency distribution for angles between pairs of bound Fabs had a single peak, at about $144^{\circ}$, indicating that the $\alpha$-subunits are non-adjacent. We then incubated the receptors with both anti-FLAG Fabs and anti-HA antibodies, to decorate both $\alpha$ - and $\delta$-subunits simultaneously. We identified receptors that had been decorated with two Fabs and one antibody. A representative image is shown in Fig. 5a. Note that the Fabs can be clearly distinguished from the whole antibody on the basis of their smaller size. Hence, we now have a method for finding the position of the $\delta$-subunit relative to that of the two $\alpha$-subunits.

The receptors are normally bound to poly-L-lysinecoated mica, which provides a positively charged surface. We speculated that the receptors would bind to this support through a negatively charged surface on the protein. This is most likely to be the extracellular domain, which contains negatively charged oligosaccharides, in contrast to the intracellular domain, which contains many positively charged amino acids. If this is indeed the case, then the orientation of the receptors should be reversed when they are bound to poly-L-glutamate-coated mica, which provides a negatively charged surface. To test these ideas, we bound receptors to the two surfaces and incubated them with either the lectin concanavalin A, which should bind to the oligosaccharides on the extracellular face of the receptor [33], or monoclonal antibody bd17, which recognises an epitope at the $\mathrm{N}$ terminus of the $\beta$-subunit [60]. We reasoned that receptors bound extracellular face down would have their binding sites for both concanavalin A and antibody bd17 occluded. Receptors decorated with smaller particles were observed after incubation with either concanavalin A or antibody bd17, irrespective of the mica coating. Significantly, however, we found that for both concanavalin A and antibody bd17, there was about twice as much binding when the receptor was bound to polyL-glutamate than to poly-L-lysine, indicating that more extracellular faces were occluded when the mica was coated with poly-L-lysine. We conclude that the receptor normally binds predominantly extracellular face down to polyL-lysine-coated mica (Fig. 5b). Armed with this information and the ability to decorate two different subunits simultaneously, we are now in a position to determine the absolute subunit arrangement within any GABA receptor containing up to three subunits.

The use of concanavalin A to determine the orientation of a protein on the mica should be applicable to many integral membrane proteins, which tend to be glycosylated on their extracellular faces. The additional use of an antibody directed against an epitope on either the extracellular or the intracellular face will obviously depend on the availability of suitable antibodies.

\section{Future perspectives}

We have recently extended our AFM-based method to a study of the subunit stoichiometry of transient receptor potential channels (TRPC). In a preliminary series of experiments, we have confirmed that TRPC1 homomers are tetrameric [7]. It is well known that TRPC subunits assemble to form a variety of heteromeric channels. Our method provides a means of addressing the subunit arrangement within these channels. It also should be applicable to a wide variety of multi-subunit proteins, including other ionotropic receptors and ion channels.

Acknowledgements We are grateful to our collaborators on the projects described in this review, especially Ruth Murrell-Lagnado, Ian Martin and Susan Dunn, and to Calum Neish who was involved in the early development of the techniques described. Our work was supported by a grant from the Biotechnology and Biological Sciences Research Council (B19797) to J.M.E. and R.M.H.

\section{References}

1. Adkins CE, Pillai GV, Kerby J, Bonnert TP, Haldon C, McKernan RM, Gonzalez JE, Oades K, Whiting PJ, Simpson PB (2001) $\alpha_{4} \beta_{3} \delta$ GABA $_{\mathrm{A}}$ receptors characterized by fluorescence resonance energy transfer-derived measurements of membrane potential. J Biol Chem 276:38934-38939

2. Aschrafi A, Sadtler S, Niculescu C, Rettinger J, Schmalzing G (2004) Trimeric architecture of homomeric $\mathrm{P} 2 \mathrm{X}_{2}$ and heteromeric $\mathrm{P} 2 \mathrm{X}_{1+2}$ receptor subtypes. J Mol Biol 342:333-343

3. Barrera NP, Ge H, Henderson RM, Fitzgerald WJ, Edwardson JM (2008) Automated analysis of the architecture of receptor, imaged by atomic force microscopy. Micron (in press)

4. Barrera NP, Henderson RM, Murrell-Lagnado RD, Edwardson JM (2007) The stoichiometry of $\mathrm{P} 2 \mathrm{X}_{2 / 6}$ receptor heteromers depends on relative subunit expression levels. Biophys J 93:505-512

5. Barrera NP, Herbert P, Henderson RM, Martin IL, Edwardson JM (2005) Atomic force microscopy reveals the stoichiometry and subunit arrangement of 5- $\mathrm{HT}_{3}$ receptors. Proc Natl Acad Sci USA 102:12595-12600

6. Barrera NP, Ormond SJ, Henderson RM, Murrell-Lagnado RD, Edwardson JM (2005) Atomic force microscopy imaging demonstrates that $\mathrm{P} 2 \mathrm{X}_{2}$ receptors are trimers but that $\mathrm{P} 2 \mathrm{X}_{6}$ receptor subunits do not oligomerize. J Biol Chem 280:10759-10765

7. Barrera NP, Shaifta Y, McFadzean I, Ward JPT, Henderson RM, Edwardson JM (2007) AFM imaging reveals the tetrameric structure of the TRPC1 channel. Biochem Biophys Res Commun 358:1086-1090

8. Baumann SW, Baur R, Sigel E (2002) Forced subunit assembly in $\alpha_{1} \beta_{2} \gamma_{2}$ GABA $_{A}$ receptors. J Biol Chem 277:46020-46025

9. Baur R, Minier F, Sigel E (2006) A $\mathrm{GABA}_{\mathrm{A}}$ receptor of defined subunit composition and positioning: concatenation of five subunits. FEBS Lett 580:1616-1620 
10. Bobanovic LK, Royle SJ, Murrell-Lagnado RD (2002) P2X receptor trafficking in neurons is subunit specific. J Neurosci 22:4814-4824

11. Boess FG, Beroukhim R, Martin IL (1995) Ultrastructure of the 5-hydroxytryptamine 3 receptor. J Neurochem 64:1401-1405

12. Boess FG, Lummis SCR, Martin IL (1992) Molecular properties

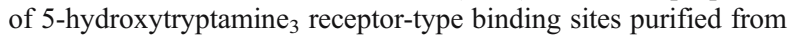
NG108-15 cells. J Neurochem 59:1692-1701

13. Brejc K, van Dijk WJ, Klaassen RV, Schuurmans M, van der Oost J, Smit AB, Sixma TK (2001) Crystal structure of an ACh-binding protein reveals the ligand-binding domain of nicotinic receptors. Nature 411:269-276

14. Brickley SG, Revilla V, Cull-Candy SG, Wisden W, Farrant M (2001) Adaptive regulation of neuronal excitability by a voltageindependent potassium conductance. Nature 409:88-92

15. Brooks-Kayal AR, Shumate MD, Jin H, Rikhter TY, Coulter DA (1998) Selective changes in single cell $\mathrm{GABA}_{\mathrm{A}}$ receptor subunit expression and function in temporal lobe epilepsy. Nat Med 4:1166-1172

16. Brown N, Kerby J, Bonnert TP, Whiting PJ, Wafford KA (2002) Pharmacological characterization of a novel cell line expressing human $\alpha_{4} \beta_{3} \delta \mathrm{GABA}_{\mathrm{A}}$ receptors. Br J Pharmacol 136:965-974

17. Cascio M (2004) Structure and function of the glycine receptor and related nicotinoid receptors. J Biol Chem 279:19383-19386

18. Celie PH, van Rossum-Fikkert SE, van Dijk WJ, Brejc K, Smit AB, Sixma TK (2004) Nicotine and carbamylcholine binding to nicotinic acetylcholine receptors as studied in AChBP crystal structures. Neuron 41:907-914

19. Chandra D, Jia F, Liang J, Peng Z, Suryanarayanan A, Werner DF, Spigelman I, Houser CR, Olsen RW, Harrison NL, Homanics GE (2006) $\mathrm{GABA}_{\mathrm{A}}$ receptor $\alpha 4$ subunits mediate extrasynaptic inhibition in thalamus and dentate gyrus and the action of gaboxadol. Proc Natl Acad Sci USA 103:15230-15235

20. Chu Y, Mouat MF, Coffield JA, Orlando R, Grider A (2003) Expression of $\mathrm{P} 2 \mathrm{X}_{6}$, a purinergic receptor subunit, is affected by dietary zinc deficiency in rat hippocampus. Biol Trace Elem Res 91:77-87

21. Clark M, Massenburg GS, Weiss SRB, Post RM (1994) Analysis of the hippocampal $\mathrm{GABA}_{\mathrm{A}}$ receptor system in kindled rats by autoradiographic and in situ hybridization techniques: contingent tolerance to carbamazepine. Mol Brain Res 26:309-319

22. Collo G, North RA, Kawashima E, Merlo-Pich E, Neidhart S, Surprenant A, Buell G (1996) Cloning of P2X $\mathrm{X}_{5}$ and P2X receptors and the distribution and properties of an extended family of ATP-gated ion channels. J Neurosci 16:2495-2507

23. Davies PA, Pistis M, Hanna MC, Peters JA, Lambert JJ, Hales TG, Kirkness EF (1999) The 5- $\mathrm{HT}_{3 \mathrm{~B}}$ subunit is a major determinant of serotonin-receptor function. Nature 397:359-363

24. Derkach V, Surprenant A, North RA (1989) 5- $\mathrm{HT}_{3}$ receptors are membrane ion channels. Nature 339:706-709

25. Dubin AE, Huvar R, D'Andrea MR, Pyati J, Zhu JY, Joy KC, Wilson SJ, Galindo JE, Glass CA, Luo L, Jackson MR, Lovenberg TW, Erlander MG (1999) The pharmacological and functional characteristics of the serotonin $5-\mathrm{HT}_{3 \mathrm{~A}}$ receptor are specifically modified by a $5-\mathrm{HT}_{3 \mathrm{~B}}$ receptor subunit. J Biol Chem 274:30799-30810

26. Durchschlag H, Zipper P (1997) Calculation of partial specific volumes and other volumetric properties of small molecules and polymers. J Appl Cryst 30:803-807

27. Egan TM, Khakh BS (2004) Contribution of calcium ions to P2X channel responses. J Neurosci 24:3413-3420

28. Farrar SJ, Whiting PJ, Bonnert TP, McKernan RM (1999) Stoichiometry of a ligand-gated ion channel determined by fluorescence energy transfer. J Biol Chem 274:10100-10104

29. Grant EH (1957) The dielectric method of estimating protein hydration. Phys Med Biol 2:17-28
30. Greger IH, Ziff EB, Penn AC (2007) Molecular determinants of AMPA receptor subunit assembly. Trends Neurosci 30:407-416

31. Groot-Kormelink PJ, Broadbent S, Beato M, Sivilotti LG (2006) Constraining the expression of nicotinic acetylcholine receptors by using pentameric constructs. Mol Pharmacol 69:558-563

32. Hussy N, Lukas W, Jones KA (1994) Functional properties of a cloned 5-hydroxytryptamine ionotropic receptor subunit: comparison with native mouse receptors. J Physiol 481:311-323

33. Im WB, Tai MM, Blakeman DP, Davis JP (1989) Immobilized $\mathrm{GABA}_{\mathrm{A}}$ receptors and their ligand binding characteristics. Biochem Biophys Res Commun 163:611-617

34. Jiang L-H, Kim M, Spelta V, Bo X, Surprenant A, North RA (2003) Subunit arrangement in P2X receptors. J Neurosci 23:8903-8910

35. Jones KA, Surprenant A (1994) Single channel properties of the $5-\mathrm{HT}_{3}$ subtype of serotonin receptor in primary cultures of rodent hippocampus. Neurosci Lett 174:133-136

36. Karlin A (2002) Emerging structure of the nicotinic acetylcholine receptors. Nat Rev Neurosci 3:102-114

37. Karlin A, Holtzman E, Yodh N, Lobel P, Wall J, Hainfeld J (1983) The arrangement of the subunits of the acetylcholine receptor of Torpedo californica. J Biol Chem 258:6678-6681

38. Kelley SP, Dunlop JI, Kirkness EF, Lambert JJ, Peters JA (2003) A cytoplasmic region determines single-channel conductance in 5$\mathrm{HT}_{3}$ receptors. Nature 424:321-324

39. Khakh BS, North RA (2006) P2X receptors as cell-surface ATP sensors in health and disease. Nature 442:527-532

40. Kim M, Yoo OJ, Choe S (1997) Molecular assembly of the extracellular domain of $\mathrm{P}_{2} \mathrm{X}_{2}$, an ATP-gated ion channel. Biochem Biophys Res Commun 240:618-622

41. King BF, Townsend-Nicholson A, Wildman SS, Thomas T, Spyer KM, Burnstock G (2000) Coexpression of rat $\mathrm{P} 2 \mathrm{X}_{2}$ and $\mathrm{P} 2 \mathrm{X}_{6}$ subunits in Xenopus oocytes. J Neurosci 20:4871-4877

42. Kukley M, Barden JA, Steinhauser C, Jabs R (2001) Distribution of $\mathrm{P} 2 \mathrm{X}$ receptors on astrocytes in juvenile rat hippocampus. Glia $36: 11-21$

43. Le KT, Villeneuve P, Ramjaun AR, McPherson PS, Beaudet A, Seguela P (1998) Sensory presynaptic and widespread somatodendritic immunolocalization of central ionotropic P2X ATP receptors. Neuroscience 83:177-190

44. Lester HA, Dibas MI, Dahan DS, Leite JF, Dougherty DA (2004) Cys-loop receptors: new twists and turns. Trends Neurosci 27:329-336

45. McKernan RM, Whiting PJ (1996) Which $\mathrm{GABA}_{\mathrm{A}}$-receptor subtypes really occur in the brain? Trends Neurosci 19:139-143

46. Maricq AV, Peterson AS, Brake AJ, Myers RM, Julius D (1991) Primary structure and functional expression of the $5 \mathrm{HT}_{3}$ receptor, a serotonin-gated ion channel. Science 254:432-437

47. Mayer ML (2006) Glutamate receptors at atomic resolution. Nature 440:456-462

48. Mio K, Kubo Y, Ogura T, Yamamoto T, Sato C (2005) Visualization of the trimeric $\mathrm{P}_{2} \mathrm{X}_{2}$ receptor with a crown-capped extracellular domain. Biochem Biophys Res Commun 337:998-1005

49. Miyazawa A, Fujiyoshi Y, Stowell M, Unwin N (1999) Nicotinic receptor at $4.6 \AA$ resolution: transverse tunnels in the channel wall. J Mol Biol 288:765-786

50. Nakazawa K, Yamakoshi Y, Tsuchiya T, Ohno Y (2005) Purification and aqueous phase atomic force microscopic observation of recombinant $\mathrm{P} 2 \mathrm{X}_{2}$ receptor. Eur J Pharmacol 518:107-110

51. Nawa G, Miyoshi Y, Yoshikawa H, Ochi T, Nakamura Y (1999) Frequent loss of expression or aberrant alternative splicing of $\mathrm{P} 2 \mathrm{XM}$, a p53-inducible gene, in soft-tissue tumours. Br J Cancer 80:1185-1189

52. Nayeem N, Green TP, Martin IL, Barnard EA (1994) Quaternary structure of native $\mathrm{GABA}_{\mathrm{A}}$ receptor determined by electron microscopic image analysis. J Neurochem 62:815-818 
53. Neish CS, Martin IL, Davies M, Henderson RM, Edwardson JM (2003) Atomic force microscopy of ionotropic receptors bearing subunit-specific tags provides a method for determining receptor architecture. Nanotechnology 14:864-872

54. Nicke A, Bäumert HG, Rettinger J, Eichele A, Lambrecht G, Mutschler E, Schmalzing G (1998) P2X $\mathrm{X}_{1}$ and P2X $\mathrm{X}_{3}$ receptors form stable trimers: a novel structural motif of ligand-gated ion channels. EMBO J 17:3016-3128

55. North RA (2002) Molecular physiology of P2X receptors. Physiol Rev 82:1013-1067

56. Nusser Z, Mody I (2002) Selective modulation of tonic and phasic inhibitions in dentate gyrus granule cells. J Neurophysiol 87:2624-2628

57. Ormond SJ, Barrera NP, Qureshi OS, Henderson RM, Edwardson JM, Murrell-Lagnado RD (2006) An uncharged region within the $\mathrm{N}$ terminus of the $\mathrm{P} 2 \mathrm{X}_{6}$ receptor inhibits its assembly and exit from the endoplasmic reticulum. Mol Pharm 69:1692-1700

58. Park HC, Seong J, An JH, Kim J, Kim UJ, Lee BW (2005) Alteration of cancer pain-related signals by radiation: proteomic analysis in an animal model with cancer bone invasion. Int J Radiat Oncol Biol Phys 61:1523-1534

59. Peters JA, Hales G, Lambert JJ (2007) Molecular determinants of single-channel conductance and ion selectivity in the Cys-loop family: insights from the 5- $\mathrm{HT}_{3}$ receptor. Trends Pharmacol Sci 26:587-594

60. Richards JG, Schoch P, Häring P, Takacs B, Möhler H (1987) Resolving $\mathrm{GABA}_{\mathrm{A}} /$ benzodiazepine receptors: cellular and subcellular localization in the CNS with monoclonal antbodies. J Neurosci 7:1866-1886

61. Rubio ME, Soto F (2001) Distinct localization of P2X receptors at excitatory postsynaptic specializations. J Neurosci 21:641-653

62. Schneider SW, Lärmer J, Henderson RM, Oberleithner H (1998) Molecular weights of individual proteins correlate with molecular volumes measured by atomic force microscopy. Pflügers Arch 435:362-367
63. Schwarzer C, Tsunashima K, Wanzenbock C, Fuchs K, Sieghart W, Sperk G (1997) $\mathrm{GABA}_{\mathrm{A}}$ receptor subunits in the rat hippocampus II: altered distribution in kainic acid-induced temporal lobe epilepsy. Neuroscience 80:1001-1017

64. Seguela P, Haghighi A, Soghomonian JJ, Cooper E (1996) A novel neuronal $\mathrm{P}_{2 \mathrm{x}}$ ATP receptor ion channel with widespread distribution in the brain. J Neurosci 16:448-455

65. Sieghart W (1995) Structure and pharmacology of gammaaminobutyric acid $_{\mathrm{A}}$ receptor subtypes. Pharmacol Rev 47:181-234

66. Soto F, Garcia-Guzman M, Karschin C, Stuhmer W (1996) Cloning and tissue distribution of a novel $\mathrm{P} 2 \mathrm{X}$ receptor from rat brain. Biochem Biophys Res Commun 223:456-460

67. Stell BM, Brickley SG, Tang CY, Farrant M, Mody I (2003) Neuroactive steroids reduce neuronal excitability by selectively enhancing tonic inhibition mediated by delta subunit-containing GABA $_{\mathrm{A}}$ receptors. Proc Natl Acad Sci USA 100:14439-14444

68. Tsunashima K, Schwarzer C, Kirchmair E, Sieghart W, Sperk G (1997) $\mathrm{GABA}_{\mathrm{A}}$ receptor subunits in the rat hippocampus. III. Altered messenger RNA expression in kainic acid-induced epilepsy. Neuroscience 80:1019-1032

69. Turner CM, Vonend O, Chan C, Burnstock G, Unwin RJ (2003) The pattern of distribution of selected ATP-sensitive P2 receptor subtypes in normal rat kidney: an immunohistological study. Cells Tissues Organs 175:105-117

70. Unwin N (2005) Refined structure of the nicotinic acetylcholine receptor at $4 \AA$ resolution. J Mol Biol 346:967-989

71. Urano T, Nishimori H, Han H, Furuhata T, Kimura Y, Nakamura Y, Tokino T (1997) Cloning of P2XM, a novel human P2X receptor gene regulated by $\mathrm{p} 53$. Cancer Res 57:3281-3287

72. Vulchanova L, Arvidsson U, Riedl M, Wang J, Buell G, Surprenant A, North RA, Elde R (1996) Differential distribution of two ATP-gated channels (P2X receptors) determined by immunocytochemistry. Proc Natl Acad Sci USA 93:8063-8067

73. Yang J, Mathie A, Hille B (1992) 5- $\mathrm{HT}_{3}$ receptor channels in dissociated rat superior cervical ganglion neurons. J Physiol 448:237-256 